\title{
DECONSTRUCTING RACIST HUMOR: HOW ARCHIE BOSTON'S ADVERTISEMENTS PROVOKE INSTITUTIONALIZED RACISM
}

\author{
Shaheila Valmai Kalyana Roeswan ${ }^{1}$, Yasmine Anabel Panjaitan ${ }^{2, *}$ \\ ${ }^{1}$ English Studies Program, Faculty of Humanities, Universitas Indonesia, Depok 16424, Indonesia \\ ${ }^{2}$ English Studies Program, Faculty of Humanities, Universitas Indonesia, Depok 16424, Indonesia
}

\section{ARTICLE INFO}

Keywords:

Archie Boston

Advertisements

Critical discourse analysis

Incongruous humor

Institutionalized racism

Visual grammar

Article History:

Received: 01/04/2021

Accepted: 17/05/2021

Available Online:

$31 / 05 / 2021$

\begin{abstract}
A B S T RACT
Humor is one of the most used mediums for overcoming the dominant power in society. One type of humor, Black Humor, was initially used by the Black community to speak their voice regarding the racism they face every day. However, it showed that even the most powerful tool could also act as a double-edged sword for its users. In this research, we analyzed three advertisements made by Archie Boston circa the 1960s that took the symbolism of the Ku Klux Klan, Uncle Sam, and slavery and turned these symbolisms into objects of humor. Using Kress and van Leeuwen's Grammar of Visual Design, Barthes' visual semiotics, and incongruity theory by Goldstein and McGhee, these advertisements were analyzed and then critically associated with the theory of Institutionalized Racism. The results revealed that these advertisements showed affiliation with how stereotypes are identified through symbolism by using humor and visual images. Therefore, these advertisements perpetuate negative stereotypes of the Black community by making Black people seem complicit in and supporting the racist acts that the symbols perpetuated.
\end{abstract}

2442-305X / (C) 2021 The Authors, this is open access article under the (CC-BY-NC) license (https://creativecommons.org/licenses/by-nc/4.0/), DOI: 10.19105/ojbs.v15i1.4522

\footnotetext{
$\overline{* \text { Corresponding Author: }}$

Email address: yasmine_pandjaitan@yahoo.com (Y. A. Panjaitan)
}

\section{A. Introduction}

Humor is one way to poke fun at things deemed severe, meaning that it is used to make fun of people's bleak situations. The marginalized people in a society have often used this power from humor to resist the dominant power. In 2000, KMV and Otpor activists' attempted to overthrow Slobodan Milošević by using barrels for people to donate money for
Milošević's retirement, humorously implying that they wanted his administration to end. ${ }^{1}$ As something thought to be innocent and harmless, humor for acts of resistance is also seen

\footnotetext{
1 Majken Jul Sorensen, "Humor as a Serious Strategy of Nonviolent Resistance to Oppression," Peace \& Change 33, no. 2 (2008): 167-68, https://doi.org/10.1111/j.1468-0130.2008.00488.x.
} 
as a relief act from pressures that exist. ${ }^{2}$ From the many types of humor, the one type of humor to assert power is black humor. Black Humor, a term coined by Andre Bréton in 1963, refers to the cynicism that the Black community uses to fight the everyday occurrence of racism. In the United States, the group uses it to confront the acts of racism they have been facing for a long time.

Research has shown that humor is effective in sending messages from the oppressed and making hegemonic groups uncomfortable. $^{3}$ However, some also argue that instead of being a powerful tool to fight racism, black humor lessens the importance of fighting racism and gives unwanted representations for the Black community. ${ }^{4}$ Another point made by Weaver shows that black humor creates ambivalence, ${ }^{5}$ which means that black humor can generate and force unwanted stereotypes due to how unclear and confusing black humor is from the point of

\footnotetext{
${ }^{2}$ Marjolein 't Hart, "Humour and Social Protest: An Introduction," International Review of Social History 52, no. S15 (2007): 6, https://doi.org/10.1017/S0020859007003094.

3 Omotayo Banjo, "What Are You Laughing at? Examining White Identity and Enjoyment of Black Entertainment," Journal of Broadcasting \& Electronic Media 55, no. 2 (2011): 137-59, https://doi.org/10.1080/08838151.2011.570822.

4 Cheryl Banks Mason, "The Dynamics of Black Humor from Africa to America and The Transformation from Slavery to the Twentieth Century" (Thesis, Atlanta, Georgia, Clark Atlanta University, 2008), https://radar.auctr.edu/islandora/object/cau.td\%3A2 008 mason cheryl b/.

${ }^{5}$ Simon Weaver, "Developing a Rhetorical Analysis of Racist Humour: Examining Anti-Black Jokes on the Internet," Social Semiotics 20, no. 5 (2010): 537-55,

https://doi.org/10.1080/10350330.2010.513188.
}

view of the users and target audience. According to Turchiano, about $62 \%$ of the Black community still feel underrepresented in the media. ${ }^{6}$ Rather than being seen as a powerful medium, black humor could potentially disrupt the representation of the Black community by perpetuating negative stereotypes as criminals, vigilantes, dirty, and many other negative associations. ${ }^{7}$

Weaver suggested that racist verbal humor may emphasize the realities of a minority group and create categorization in the community. ${ }^{8}$ In another study, according to Baig et al. in 2019, humorous advertisements could reinforce feminine stereotypes even when the only intention is to promote a product by drawing upon the patriarchal ideology. ${ }^{9}$ Not only that, in

6 Danielle Turchiano, "Two in Three Black Americans Don't Feel Properly Represented in Media (Study)," Variety (blog), September 17, 2020, https://variety.com/2020/tv/news/representationmatters-study-nrg-black-americans-media1234772025/.

7 Karim Murji, "Using Racial Stereotypes in AntiRacist Campaigns," Ethnic and Racial Studies 29, no. 2 (2006): 260-80, https://doi.org/10.1080/01419870500465488; Clara Castelar Orteu, "The Ethics of Intercultural Translation: Analysing the Figure of the African and African- American in Contemporary Spanish Television Advertising between 20th and 21st Centuries" (Dissertation, Universitat de les Illes Balears, 2020), http://dspace.uib.es/xmlui/handle/11201/152507.

${ }^{8}$ Simon Weaver, "Developing a Rhetorical Analysis of Racist Humour: examining anti-black jokes on the internet, Social Semiotics 20, no. 5 (2010): 537-55, http://dx.doi.org/10.1080/10350330.2010.513188." 9 Fatima Zafar Baig et al., "Humor as Monotony Breaker in Funny Ads: A Multi-Modal Discourse Analysis of Ads of Pakistani Ufone \& Jazz Cellular Companies," International Journal of English Linguistics 10, no. 1 (2019): 69-80, https://doi.org/10.5539/ijel.v10n1p69. 
a study conducted by Murji, advertisements to promote anti-racism backfired when they decided to use humor as it reinforced the notion of Black people being "scary" and that people should be afraid of them. ${ }^{10}$ These dispreferred responses show that humor requires a specific level of understanding from its audience. Often the problem is that humor, especially confrontational ones, might be misunderstood by its audience. ${ }^{11}$

Yoon found that racist Internet memes can also perpetuate existing stereotypes with their hidden ideology of colorblindness, where racism is still reinforced but in a more subtle way, such as diminishing the idea that racism no longer exists or blaming an individual for their lack of achievement, not due to their lack of privilege. ${ }^{12}$ Through her research, we can see the correlation between visual media, humor, and hidden racist ideologies, of which the correlation of the three is still rarely discussed. As we touch upon the lack of study concerning visual media, especially in advertisements, Archie Boston becomes the case study of this research. Archie Boston is an AfricanAmerican graphic designer that has

${ }^{10}$ Karim Murji, "Using Racial Stereotypes in AntiRacist Campaigns," Ethnic and Racial Studies 29, no. 2 (2006): 260-80, https://doi.org/10/1080/014198705000465488

11 Donald A. Saucier et al., "'What Do You Call a Black Guy Who Flies a Plane?': The Effects and Understanding of Disparagement and Confrontational Racial Humor," Humor 31, no. 1 (2018): 105-28, https://doi.org/10.1515/humor2017-0107.

12 InJeong Yoon, "Why is it not Just a Joke? Analysis of Internet Memes Associated with Racism and Hidden Ideology of Colorblindness," Journal of Cultural Research in Art Education 33 (2016): 62123. notably won several awards, including the AIGA, which stands for American Institute of Graphic Arts, Fellows Awards in $2007 .^{13}$ His popular advertisements include Black men being tied to historical, often racist, symbolisms. It is undeniable that without a deep understanding of the imageries, one could argue that he could misrepresent or perpetuate unwanted stereotypes for the Black community, where they could be regarded as supportive towards harmful acts targeted at them.

There will be three main theories used in this study. The first is critical race theory. It refers to the movement that questions and transforms the relationship between race, power, and racism. The theory, by Delgado \& Stefancic, ${ }^{14}$ is derived from radical feminism and critical legal studies in the 1970s. The second theory is critical discourse analysis by Weissenrieder and Fairclough. ${ }^{15}$ It helps to explain the discursive nature of the ads. Lastly, Barthes' theory of visual semiotics reveals the connotative meanings of the data.

Therefore, by looking at previous research, and how no research has touched upon Archie Boston's advertisements, this research aims to analyze Archie Boston's advertisements

\footnotetext{
13 Alan Rapp, "Archie Boston's Design Journey," AIGA | the professional association for design, accessed April 13, 2021, https://www.aiga.org/design-journeys-archieboston.

14 Delgado Richards and Jean Stefancic, Critical Race Theory: An Introduction, 3rd ed. (New York: New York University Press, 2017).

${ }^{15}$ Maureen Weissenrieder and Norman Fairclough, "Critical Discourse Analysis: The Critical Study of Language," The Modern Language Journal 81, no. 3 (1997): 428, https://doi.org/10.2307/329335.
} 
due to the racial implications that they may have by using critical race theory and critical discourse analysis and unmasking the relation between humor and reinforcement of stereotypes in the Black community. This research focuses on using the theory of institutionalized racism, Kress and van Leeuwen's visual design theory, and Barthes' theory of visual semiotics to answer how Archie Boston's advertisements create negative stereotypes still affecting the Black community until today.

\section{B. Method}

The data consisted of three print advertisements made by Archie Boston. These advertisements were accessed in October 2020 through the American Institute of Graphic Arts' website, which stores Archie Boston's online interview and a short autobiography. All three of these advertisements were made around the 1960s, and as said by Archie Boston himself, his provocative and shocking advertisements were intended to challenge the "currently ongoing racial dynamic shift at the time."16 The print advertisements include the imagery which is often associated with the Black history, which is the depiction of slavery, the KKK (Ku Klux Klan) costume, and Boston himself dressing as Uncle Sam, the icon of the federal government in the United States, which is supposed to be an ironic statement for the Black community. To find out how much humor and visual images strengthen each other in

${ }^{16}$ Rapp, "Archie Boston's Design Journey." reinforcing stereotypes, we analyzed the previously mentioned print advertisements using critical race theory as the theoretical framework and critical discourse analyses as the research methodologies.

This research used a qualitative approach, and the procedures were divided into three steps. The first step in analyzing the corpus is analyzing the visual and verbal aspects of the three advertisements using the visual grammar theory created by Kress and van Leeuwen, $^{17}$ which includes semiotic analysis using Barthes' visual semiotics approach. ${ }^{18}$ After that, black humor was examined under critical race theory, focusing on institutionalized racism. The last step of the research was to see the relation between the humor and visualverbal aspects in the advertisements.

\section{Results}

\section{Visual Grammar of the Advertisements}

In this section, we will look at the aspects mentioned in Kress and van Leeuwen's theory. First, we will look at the Participants, specifically the represented participant, to refer to the advertisements' elements for representational meaning. We will refer to these participants as Actor/Carrier to emphasize the action they create for the audience to see and their connection by referring to them as Vectors. Meanwhile, using the term

\footnotetext{
17 Gunter Kress and Theo van Leeuwen, Reading Images: The Grammar of Visual Design, 2nd ed. (New York: Routledge, 2006).

18 Theo Van Leeuwen and Carey Jewitt, The Handbook of Visual Analysis (London: SAGE Publications, 2001), 91-99.
} 
Carrier will make it easier to identify the men in the advertisements by looking at their Possessive Attributes, which makes the carrier 'what they are' and categorizes them. For the interpersonal meaning, we will look at the gestures and facial expressions that the people in the advertisements make and relate them with how the audience will perceive them. Lastly, we will look at the composition of the advertisement, focusing on the framing, salience, and values of the elements in the advertisements. These aspects will contribute to showing how the advertisements want to incite specific reactions from the audience.

The similarities between the three advertisements created by Boston are that they are in black and white. In all three advertisements, the Actors always looked straight into the audience, creating an invisible gaze to connect the audience to the advertisements. These men act as the represented participant in the advertisements. The frontal angle of the shots also suggested that they need maximum attention from the audience. Not only that, but all three advertisements also included Black men, which can be deduced by looking at their Possessive Attributes, skin color, and facial features. These men are also the most salient object in the advertisement since all men stood out compared to their background, emphasizing the need for the audience to focus on these men. Next, all three advertisements are presented at eye level, which means that Boston wanted to emit equality and no power differences between the represented and interactive participants.

Lastly, all three advertisements use the white framing around the picture and have similar wording underneath them, with customization following the symbols they represent. The white framing emphasizes the importance of the image, especially since all advertisements have similar formatting, where the area of the picture is more significant than the text. According to Kress and van Leeuwen, ${ }^{19}$ this showed the Ideal-Real relationship, where the text serves to elaborate the picture, which is rich in symbolism. All symbolisms will be further explained in the subsections below.

\section{a. First Advertisement}

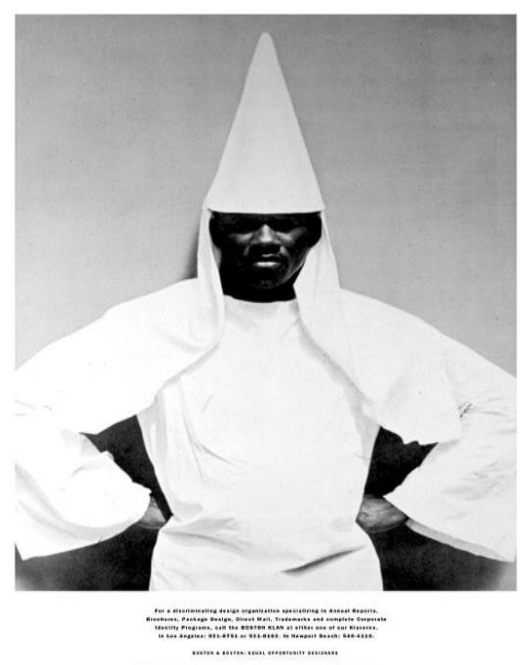

Fig. 1. Ku Klux Klan Advertisement

Figure 1 depicts a man wearing a $\mathrm{Ku}$ Klux Klan attire. This advertisement was published in 1966, when the Ku Klux Klan activities were resurfacing, especially in the Southern area, due to the Civil

\footnotetext{
${ }^{19}$ Gunter Kress and Theo van Leeuwen, Reading Images: The Grammar of Visual Design, 2nd ed. (New York: Routledge, 2006), 186-88.
} 
Rights Act of $1964 .{ }^{20}$ The advertisement is divided into two parts, the image and the text below it. The image is a picture of a man wearing cult attire, and the text below it reads:

"For a discriminating design organization specializing in Annual Reports, Brochures, Package Design, Direct Mail, Trademark and complete Corporate Identity Programs, call the BOSTON KLAN at either one of our Klaverns in Los Angeles: 931-8751 or 931-6163. In Newport Beach: 5404110. BOSTON \& BOSTON: EQUAL OPPORTUNITY DESIGNERS."

The man in the picture is standing in the middle, alone, and is looking straight at the audience. He is posing with hands on his hips to assert himself into a situation and look at the man's Possessive Attributes. It is seen that the man is wearing Ku Klux Klan attire. The image of the man is in black and white, showing the contrast between the black man and the white attire. Although lacking in color, the image has a higher modality since it shows the textures on the man's hands and facial expression. The use of contrasting values and textures on the participant is made to draw our attention primarily to him. The image acts as the attention grabber and the emotive appeal, while the bottom part explains their services. The Ideal-Real relationship between the image and the text shows white supremacy by using the symbolism of the Ku Klux Klan and showing the message through the visuals. By using Barthes' visual semiotics theory, it is

20 "Ku Klux Klan | Definition \& History," Encyclopedia Britannica, accessed April 13, 2021, https://www.britannica.com/topic/Ku-Klux-Klan. possible to look at the layer of meanings of the advertisement, which looks as follows:

\section{Table 1.}

Denotative and Connotative Meaning of the Ku Klux Advertisement

\begin{tabular}{|c|c|}
\hline Denotative Signifier & Denotative Signified \\
\hline $\begin{array}{l}\text { 1. A man with a } \\
\text { darker skin tone }\end{array}$ & 1. A black man \\
\hline 2. Ku Klux Klan attire & $\begin{array}{l}\text { 2. Involvement with } \\
\text { the Ku Klux Klan }\end{array}$ \\
\hline Connotation & \\
\hline
\end{tabular}

The focus of this advertisement is a Black man that is wearing $\mathrm{Ku}$ Klux Klan attire. The man is shown with his hands on his hips, indicating that he asserts some sort of power towards the viewers. By wearing a $\mathrm{Ku}$ Klux Klan attire, the assumption is that the man supports the actions and ideologies that the Ku Klux Klan holds, as the attire itself is a symbol of involvement with the Klan itself.

Ku Klux Klan is a racist-extremist group that specifically targets Black Americans and any white people that tries to help them. ${ }^{21}$ During the 1960 s, the Klan played a significant part in opposing the civil rights movements. The actor's attire is regarded as part of the hate-speech symbol in the eyes of the Black community. ${ }^{22}$ Wearing the attire, the man arguably confines to the Ku Klux Klan's actions, making him an affiliate, especially since the attire is exclusive to the Ku Klux Klan members. The text acts as a

21 Michael Billig, "Humour and hatred: the racist jokes of the Ku Klux Klan," Discourse \& Society 12, no. 3 (2001): 271, https://doi.org/10.1177/0957926501012003001; David Cunningham, Klansville, U.S.A.: The Rise and Fall of the Civil Rights-Era Ku Klux Era (New York: Oxford University Press, 2012), 6.

22 Kelly J. Baker, Gospel According to the Klan: The KKK's Appeal to Protestant America, 1915-1930 (Kansas: University Press of Kansas, 2011). 
complementary participant, and it seems to implement specific characteristics from the Ku Klux Klan. The texts, BOSTON KLAN and Klaverns, point to the Klan in $\mathrm{Ku}$ Klux Klan and their local chapters to gather, better known as 'Klavern. ${ }^{23}$

\section{b. Second Advertisement}

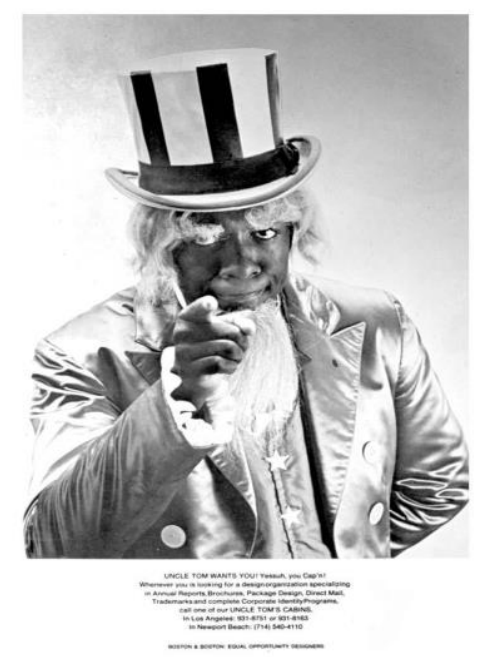

Fig. 2. Uncle Sam Advertisement

The second advertisement was created in 1967, which was simultaneous with the Vietnam War drafting. This advertisement depicts a man dressing up as Uncle Sam, the symbol of the federal government of America. The advertisement is divided into two parts: the image and the text. The text below the image reads:

"UNCLE TOM WANTS YOU! Yessuh, you Cap'n! Whenever you are looking for a design organization specializing in Annual Reports, Brochures, Package Design, Direct Mail, Trademark and complete Corporate Identity Programs, call one of our UNCLE TOM'S CABINS. In LOS Angeles: $931-8751$ or 931-8163. In Newport Beach: (714) 540-4110. BOSTON \& BOSTON: EQUAL OPPORTUNITY DESIGNERS."

${ }^{23}$ David Cunningham, Klansville, U.S.A.: The Rise and Fall of the Civil Rights-Era Ku Klux Era (New York: Oxford University Press, 2012), 4.
The man in the image is located in the middle. Alone and looking straight to the audience, he is pointing directly at the audience. Using Barthes' layering of meaning, we would look at the image's denotative and connotative meaning.

Table 2.

Denotative and Connotative Meaning of Uncle Sam Advertisement

\begin{tabular}{ll}
\hline Denotative Signifier & Denotative Signified \\
\hline $\begin{array}{ll}\text { 1. A man with a } \\
\text { darker skin tone }\end{array}$ & 1. A black man \\
2. Uncle Sam attire & 2. $\begin{array}{l}\text { Association with } \\
\text { the United States } \\
\text { federal } \\
\text { government }\end{array}$ \\
&
\end{tabular}

\section{Connotation}

The Black man is dressing up as Uncle Sam, a symbol known as the United States federal government. The man points his index finger to the viewer as if wanting the viewer to follow his words and do as he says. The assumption is that the man is trying to embody Uncle Sam in the picture. Therefore, dressing up as Uncle Sam implies that the man wanted the viewers to follow his orders and persuade them to do as he says.

The Actor/Carrier is wearing a notable Possessive Attribute that shows his relation with Uncle Sam's character. Uncle Sam has been an iconic figure, especially during the 1860 s and the 1870 s, with its most popularized form created by James Montgomery Flagg in 1917. Uncle Sam is a white man bearing the attributes such as "having long white hair and chin whiskers and dressed in a swallow-tailed coat, vest, tall hat, and striped trousers." ${ }^{24}$ In the image, the actor

\footnotetext{
${ }^{24}$ The Editors of Encyclopaedia Britannica, "Uncle Sam | History, Artist, Drawing, Propaganda, \& Facts," Encyclopedia Britannica, May 5, 2020, https://www.britannica.com/topic/Uncle-Sam.
} 
is seen wearing those attributes. Therefore, it can be said that the black man is dressing up as Uncle Sam.

The Actor/Carrier shows a pointing gesture. From the audience's point of view, he points at the audience using his index finger, while his right hand was hidden in the back of his body. The facial expression he makes shows a firm and aggressive mode, as he looks straight to the audience and is clasping his mouth. The gesture, pointing the finger, is a universally understood way of communicating. It carries meanings that people of all ages and cultures easily understand. Pointing someone with your finger brings a sense of immediacy as it brings and steers the audience's attention with some act of forcefulness. The audience, to some extent, is involved in the actor's actions. Because of its efficiency, immediacy, and flexibility, pointing is often used where words or other means of communication fail to deliver. ${ }^{25}$ By pointing his finger, the man mimics Uncle Sam and emphasizes the message for the audience to receive and for the audience to act upon the advertisement's message. This also serves as an "image act" that further demands and invites the audience to engage with them.

The text below the image, as mentioned before, acts as a complementary subject. In this advertisement, Boston used the words, "UNCLE TOM WANTS YOU! Yessuh, you

\footnotetext{
${ }^{25}$ Kensy Cooperrider, "Fifteen Ways of Looking at a Pointing Gesture," preprint (PsyArXiv, April 3, 2020), https://doi.org/10.31234/osf.io/2vxft.
}

Cap'n!" and "UNCLE TOM'S CABINS." Uncle Tom refers to the character in the novel by Harriet Beecher Stowe, published in 1852, which depicts vivid imagery of slavery. Uncle Tom's Cabin tells us about an ideal person: saintly, domestic, and compliant, that still bears the attitude of a Christian even in tribulation. ${ }^{26}$

However, Spingarn explains that Uncle Tom in popular plays depicts Uncle Tom as someone that will sell out any other Black people to please any White person and win their favor. ${ }^{27}$ Therefore, Boston foregrounded the texts "UNCLE TOM" and "UNCLE TOM'S CABIN" to show how people in that period see the Black community.

The text also showed the usage of Eye Dialect, a term by George P. Krapp coined in 1926, which bears the characteristics of dialectical variations of spellings for certain words. ${ }^{28}$ In this advertisement, the sentence "Yessuh, you Cap'n!" is a dialectical variation of the standard English sentence, "Yes sir, you Captain!" The use of eye dialect also correlates with how Stowe uses it whenever Uncle Tom is speaking, which according to Tricomi, is to "indicate a spoken dialect," highlight the speaker's ignorance, and give information that the

\footnotetext{
26 Jo-Ann Morgan, Uncle Tom's Cabin as Visual Culture (Columbia, University of Missouri Press, 2007).

27 Adena Spingarn, Uncle Tom: From Martyr to Traitor (Stanford: Stanford University Press, 2018).

28 David Brett, "Eye Dialect: Translating the Untranslatable" Lost in Translation. Testi e culture allo specchio, AnnalSS 6 (2009): 49-62.
} 
speaker is a lower-class citizen. ${ }^{29}$ Tricomi also suggested that eye dialect can be regarded as "black dialect," and its usage borders on offensive and condescending, as it is heavily related to the idea of slavery and illiteracy. Therefore, Boston implementing the dialect further showed how the person in the advertisement is a member of the Black community by relating it to the eye dialect's historical context.

\section{c. Third Advertisement}

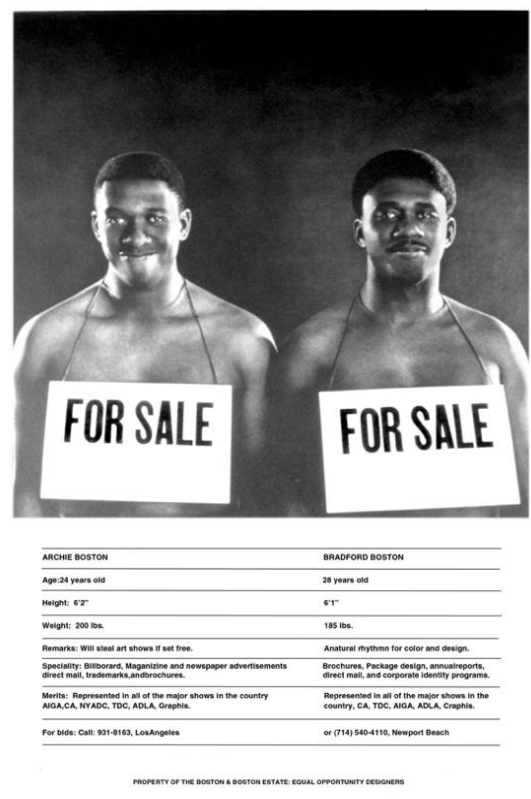

Fig. 3. 'For Sale' Advertisement

The third advertisement depicts two men presumably standing and looking to the audience. Both shirtless men had a sign on their necks that say, "FOR SALE." Below the image is a text that entails the description of both men.
Table 3.

Text Below the 'For Sale' Advertisement

\begin{tabular}{|c|c|}
\hline ARCHIE BOSTON & BRADFORD BOSTON \\
\hline Age: 24 years old & 28 years old \\
\hline Height: 6'2" & $6 ’ 1 "$ \\
\hline Weight: 200 lbs. & $185 \mathrm{lbs}$. \\
\hline $\begin{array}{l}\text { Remarks: Will steal } \\
\text { art shows if set free. }\end{array}$ & $\begin{array}{l}\text { Natural rhythm for color } \\
\text { and design. }\end{array}$ \\
\hline $\begin{array}{l}\text { Specialty: Billboard, } \\
\text { Magazine and } \\
\text { newspaper } \\
\text { advertisements direct } \\
\text { mail, trademarks, and } \\
\text { brochures. }\end{array}$ & $\begin{array}{l}\text { Brochures, Package } \\
\text { design, annual reports, } \\
\text { direct mail, and } \\
\text { corporate identity } \\
\text { programs. }\end{array}$ \\
\hline $\begin{array}{l}\text { Merits: Represented } \\
\text { in all of the major } \\
\text { shows in the country } \\
\text { AIGA, CA, NYADC, } \\
\text { TDC, ADLA, Graphis. }\end{array}$ & $\begin{array}{l}\text { Represented in all of } \\
\text { the major shows in the } \\
\text { country, CA, TDC, } \\
\text { AIGA, ADLA, Graphis. }\end{array}$ \\
\hline $\begin{array}{l}\text { For bids: Call: } 931- \\
\text { 8163, Los Angeles }\end{array}$ & $\begin{array}{l}\text { Or (714) 540-4110, } \\
\text { Newport Beach }\end{array}$ \\
\hline
\end{tabular}

The text ends with, "PROPERTY OF THE BOSTON \& BOSTON ESTATE: EQUAL OPPORTUNITY DESIGNERS."

The two men are standing next to each other and smiling at the audience. Both men are seen shirtless, only wearing a sign on their necks. Because of this, it can be deduced that the two men represent objects being sold off. The two men look like the most salient participant of the image but nearly blended into the background due to the slight difference in values. Using Barthes' visual semiotics, we can look at the image through its denotative signifier and signified, listed in Table 4.

\footnotetext{
${ }^{29}$ Albert H. Tricomi, "Dialect and Identity in Harriet Jacobs's Autobiography and Other Slave Narratives," Callaloo 29, no. 2 (2006): 619-33, https://doi.org/10.1353/cal.2006.0125.
} 
Table 4.

Denotative and Connotative Meaning of the 'For Sale' Advertisement

\begin{tabular}{|c|c|}
\hline Denotative Signifier & Denotative Signified \\
\hline $\begin{array}{l}\text { 1. Two men with a } \\
\text { darker skin tone }\end{array}$ & 1. Two Black men \\
\hline 2. 'For Sale' sign & $\begin{array}{l}\text { 2. Associating the } \\
\text { two men with the } \\
\text { act of selling and } \\
\text { buying }\end{array}$ \\
\hline $\begin{array}{l}\text { 3. Descriptive text of } \\
\text { the two men }\end{array}$ & $\begin{array}{l}\text { 3. Showing the } \\
\text { characteristics of } \\
\text { each man and } \\
\text { what are they } \\
\text { able to do, to be } \\
\text { presented for the } \\
\text { audience }\end{array}$ \\
\hline \multicolumn{2}{|l|}{ Connotation } \\
\hline \multicolumn{2}{|c|}{$\begin{array}{l}\text { The two Black men are wearing a sign on their } \\
\text { neck that says 'For Sale' and are shown smiling } \\
\text { at the viewers. This sign is mainly used for } \\
\text { actions of transactions. Therefore, the two Black } \\
\text { men are sold here, as they are the ones wearing } \\
\text { the sign. Therefore, the assumption is that the } \\
\text { Black men are depicted as an object of the } \\
\text { transaction, something that often happens in the } \\
\text { early days of slavery, and that they are happy } \\
\text { being depicted as that by them smiling. }\end{array}$} \\
\hline
\end{tabular}

The Actors wear 'For Sale' signs against a white background, which contrasts their skin color and has a fully capitalized text. The white base makes the sign stand out even more, especially since the white color is the same tone as the framing. By doing this, Boston is drawing attention to the sign that the two men wore. By doing this, Boston emphasized the action of the two men wearing the sign. However, this sign resonates with the act of slavery that Black people went through in the past. Many Africans, reaching hundreds of thousands, were kidnapped and forced to do labor work, mostly on cotton and tobacco fields. Following the trans-Atlantic slave trade, the system of slavery changed into a commercial system. ${ }^{30}$ Using the words 'For Sale' indirectly made a connection with this event in American history.

Both of the Actors/Carriers show a happy expression. They are smiling and looking straight to the audience. Their smiles towards the audience suggest a warmer attitude towards the audience. Kress and van Leeuwen also pointed out that smiling invites the audience to engage with them. ${ }^{31}$ Therefore, putting these men in a happy expression even though they face such unfortunate circumstances becomes the humor and punchline offered in this advertisement. They stand side-by-side, and only their waist up is available for view for the audience. As they are standing and looking upfront, they are presumably showing the audience that they are 'lining up,' which is connected to their lining up as if waiting to be picked by a customer, in this case, the client design services. Although there is a different value between the two men and the background, using a black and white photograph only showed how the two men can carefully blend themselves into the background, as if to show that they are invisible enough so that the audience will

\footnotetext{
${ }^{30}$ Mary Elliot and Jazmine Hughes, "A Brief History of Slavery That You Didn't Learn in School - The New York Times," The New York Times Magazine, August 19, 2019, https://www.nytimes.com/interactive/2019/08/19/ma gazine/history-slavery-smithsonian.html.

${ }^{31}$ Gunter Kress and Theo van Leeuwen, Reading Images: The Grammar of Visual Design, 2nd ed. (New York: Routledge, 2006), 116-23.
} 
not pick them, but also still very visible, especially with the sign that hangs around their neck.

In this advertisement, the text explains the two men's physique and general data, but then it is followed by their specialty in graphic design and where to contact them. The layout of the text also differs. The text is laid out in a table-like layout, clearly laying out the data of the two men, making the audience more aware of whom they are hiring for their projects.

\section{The Humor in the Advertisements}

Through all three advertisements, it is arguable that Boston uses the humor's theory of incongruity, which means that there is a conflict between the thought process and the perception of the joke. According to Snape, incongruity could work in graphic design through the notion of norms and expectations. ${ }^{32}$ Following the initial conditions needed to group certain humor into incongruity humor, Junco proposed that the mentioned outline be simplified into three main concepts: "suitable contextualization, significant transgression of concepts, and complicity with the proposed fantasy" to analyze graphic humor. ${ }^{33}$

Boston uses symbolisms in his three advertisements, which acts as the basis of black humor. The symbols are closely

\footnotetext{
32 Jason J. Snape, "Humor as an Element in Graphic Design" (Thesis, Rochester Institute of Technology, 1993), https://scholarworks.rit.edu/theses/4746.

${ }^{33}$ Manuel Alvarez Junco, "Designing the Incorrect. (Design and Graphic Humor," Design Discourse 3, no. 2 (2008): 1-16.
}

related to historical aspects, including racism towards the Black community. It is possible that the ads were intended to mock the 'original' actors, or the oppressors, who were absent from the pictures. The absence of the oppressors shows the lack of their accountability. Also, the ads show historical inaccuracies: that the black people were the KKK (Fig 1), Uncle Sam (Fig 2), and the happy slaves. These should raise questions from the audience regarding who the main actors were and why they were not rightly persecuted. Instead, life continued as if nothing had ever happened, and black people should accept it solemnly (with a warm smile).

However, the black humor in these advertisements is incongruous because it should follow a set of notions and expectations. Without clear explanations, the audience will not have a clear idea of reacting to the humor. Thus, they might act accordingly to a set of expectations, not following what Boston had in mind. The audience can misinterpret the humor that Boston had infused in the advertisements. For example, in the first and third advertisements, the symbols depicted are the Ku Klux Klan and slavery symbolisms. There is an element of complicity since the men wear the symbols: the Ku Klux Klan attire and the 'For Sale' sign. Junco explained that using a humorous character could "exhibit a radically negative image with serious defects" for the people in the image. ${ }^{34}$ In this case, Boston unwittingly might have

34 Junco, 12. 
created an idea that the Black community is complicit in creating representations that show how the Black community also supports the Ku Klux Klan or the idea of slavery. The humor used in these advertisements is then problematic since it created repercussions towards the Black community, undoubtedly representations, and stereotypes that the Black community would not want to be affiliated with as it harms the community due to the actions and wrongdoings that they have received from the clan, and also how slavery was the cause for the unequal treatments that the Black community received.

In the second advertisement, however, a different type of incongruous humor is used. In this advertisement, Boston applied Fantasy Assimilation by McGhee, ${ }^{35}$ highlighting how confusing humor is, especially when people try to mix the "inconsistent expectancy of a symbol into existing myths without prior knowledge given to the viewers." ${ }^{36}$ Boston assimilated the symbolism of Uncle Sam and Uncle Tom, two icons that are on the opposite ends of each other, as Uncle Tom is the icon of rebellion during the time both of these icons exist. As mentioned in the previous section, Uncle Tom is not only a figure of rebellion from the Black community, but Uncle Tom has also been whitewashed to fit the idea of Whites' entertainment. Therefore, it would be confusing for the viewers to read this

${ }^{35}$ McGhee in Jeffrey H. Goldstein, The Psychology of Humor: Theoretical Perspectives and Empirical Issues (Cambridge: Academic Press, 2013), 64.

${ }^{36}$ Jeffrey $\mathrm{H}$. Goldstein, The Psychology of Humor: Theoretical Perspectives and Empirical Issues (Cambridge: Academic Press, 2013), 61-69. advertisement as there are two meanings behind Uncle Tom, of which one is more offensive than the others. In this advertisement, humor is then offensive not only for the Black community but also other communities that fell under the category of citizens of the United States as the image of Uncle Sam also represents them. Uncle Sam is such an empowering figure, it would be problematic to assimilate the two characters, especially since one has racist undertones and its importance is diminished to only being a laughing stock.

\section{Humor and Institutionalized Racism}

As mentioned in the method section before, institutionalized racism is a part of critical race theory. It is essential to relate how the humor used in the advertisement will create specific nuances and reinforce them in society. This theory will show how the humor in the three advertisements is problematic as it plays on the element of incongruity. The three events of institutionalized racism that will be correlated to the humor will be the Ku Klux Klan as a racist clan, discrimination towards the Black community in the military and workforce, and slavery and how it impacts life advancements of the Black community. These events are also related to one another as one event is the cause of the other and showing the root of the problem is the focus of institutionalized racism.

First, the act of slavery is the most impactful towards the Black community. Slavery is a massive part of shaping how the Black community can finally have their 
voice and slowly receive equal treatment in society. Shaffer pointed out that slavery is responsible for illiteracy, which is arguably the most important in diminishing their voices and restricting the development of the Black community. ${ }^{37}$

The slavery and illiteracy here then act as the root of the Black community's problems in the other two advertisements. Illiteracy shows its effect on militaryrelated activities, such as the acceptance rate of Civil War pensions and treatment of the Black community in the military. The black community was known to have less acceptance rate during drafting since they were classified as having "mental deficiency" due to being illiterate, and were more likely to be rejected for pension claims because the bureaucratic process is putting the Black community at a disadvantage due to how it relies on their literary ability. ${ }^{38}$ The effect of slavery also continued towards a more "modern" society, where the Black community is now more advanced and has since received a better education and academic training. However, even in this period, the Black community still receives secondclass citizens' treatment by being limited to pursue some levels of education by the White community, and the presence of the $\mathrm{Ku}$ Klux Klan during the 1960s only proved further to put the Black

37 Donald R. Shaffer, "I Do Not Suppose That Uncle Sam Looks at the Skin': African Americans and the Civil War Pension System, 1865-1934," Civil War History 46, no. 2 (2000): 132-47, https://doi.org/10.1353/cwh.2000.0049.

38 Robert F. Engs, "Historical Perspectives on the Problem of Black Literacy," Educational Horizons 66, no. 1 (1987): 13-17, https://www.jstor.org/stable/42926188. community's lives in danger. The Ku Klux Klan also believes that the White supremacists will rule over the Black community, of which the idea is also a product of slavery in the past, where the White community rules over the Black community. $^{39} \mathrm{Ku}$ Klux Klan is also responsible for the Black community's mistreatments, such as killing and hurting the Black community to their pleasure and advantage. This shows how one event, slavery, began as the root of institutionalized racism and other racebased mistreatments that the Black community face in their lives.

Our analysis shows that affiliating humor and these symbolisms are offensive and dangerous towards the advancements of the Black community. Humor will also be responsible for reinforcing stereotypes and reinforcing the racial ideology behind said stereotypes. All three advertisements implement the racial ideology by basing it on the incongruity of black humor. However, such humor is proven ineffective since it has risks of differing depiction between viewers due to the unexpected nature. ${ }^{40}$ Whenever these symbolisms are used, there is a reinforcement of racial ideology that emphasizes the mistreatments and inequalities that the Black community went through. As the effects of said symbols are still able to be felt even until

\footnotetext{
${ }^{39}$ Editors of History.com, "Ku Klux Klan," History, November 2, 2020, https://www.history.com/topics/reconstruction/kuklux-klan.

40 Jeffrey H. Goldstein, The Psychology of Humor: Theoretical Perspectives and Empirical Issues (Cambridge: Academic Press, 2013), 61-69.
} 
today, using humor in a racially infused advertisement would only damage the employment rate of people in the Black community, as these advertisements initially have the purpose to promote Boston so that the agency can gain some clients. Shierholz showed that from the 1960s until now, the Black unemployment rate is 2 or 2.5 times more compared to the White unemployment rate. ${ }^{41}$ Therefore, it would be harmful to combine humor and these symbolisms as it could confuse the viewers' perception of the images and how the viewers' will perceive people in the Black community.

\section{Conclusion}

In conclusion, the three advertisements made by Archie Boston created and perpetuated negative stereotypes from the usage of humor and underlying racial ideology as they reinforced racist acts and slurs towards the Black community. We found that the racial ideology represented in the advertisements is divided in two ways, first by showing complicity with the symbolisms and second by assimilation of two notable symbols. The findings suggest that humor in advertisements is not practical since humor is dependent on the audience's knowledge and perception. Therefore, using incongruous humor in advertisements that are believed to be anti-discriminatory and is meant to give

${ }^{41}$ Heidi Shierholz, "Likely That Nearly One in Five Black Workers was Unemployed at Some Point in 2013," Economic Policy Institute, accessed April 13, 2021, https://www.epi.org/publication/blackworkers-unemployed-point-2013/. voice towards the marginalized group, in this case, the Black community, will only result in reinforcement of negative stereotypes. Furthermore, assimilation between symbolism and humor will also be problematic as the action would support the racial ideology and create other stereotypes towards the people in the images that would impact the overall community as people in these images are treated as their representatives. The advertisements showed that using black humor in the context and relation to institutionalized racism will only confirm these negative stereotypes that other communities, especially the White community, have towards the Black community.

This research contributes to how graphic design and humor work together in conveying the underlying messageconsidering that in mind, it is only wise to approach further the topic of humor and its effect on a marginalized group with appropriate theories that will highlight the more problematic side of the humorous elements. Future research can include audience reception that may strengthen the findings of this research.

\section{References}

Anti-Defamation League. "Ku Klux Klan Robes." Anti-Defamation League, 2021.

https://www.adl.org/education/refere nces/hate-symbols/kkk-robes.

Baig, Fatima Zafar, Saima Umer, Muhammad Zammad Aslam, Muhammad Shehzad Razaq, Samina Khan, and Tauseef Ahmad. "Humor as Monotony Breaker in 
Funny Ads: A Multi-Modal Discourse Analysis of Ads of Pakistani Ufone \& Jazz Cellular Companies." International Journal of English Linguistics 10, no. 1 (2019): 69-80. https://doi.org/10.5539/ijel.v10n1p69.

Banjo, Omotayo. "What Are You Laughing at? Examining White Identity and Enjoyment of Black Entertainment." Journal of Broadcasting \& Electronic Media 55, no. 2 (2011): 137-59. https://doi.org/10.1080/08838151.20 11.570822.

Castelar Orteu, Clara. "The Ethics of Intercultural Translation: Analysing the Figure of the African and African- American in Contemporary Spanish Television Advertising between 20th and 21st Centuries." Dissertation, Universitat de les Illes Balears, 2020. http://dspace.uib.es/xmlui/handle/11 201/152507.

Cooperrider, Kensy. "Fifteen Ways of Looking at a Pointing Gesture." Preprint. PsyArXiv, April 3, 2020. https://doi.org/10.31234/osf.io/2vxft.

Editors of History.com. "Ku Klux Klan." History, November 2, 2020. https://www.history.com/topics/reco nstruction/ku-klux-klan.

Elliot, Mary, and Jazmine Hughes. "A Brief History of Slavery that You Didn't Learn in School - The New York Times." The New York Times Magazine, August 19, 2019. https://www.nytimes.com/interactive/ 2019/08/19/magazine/historyslavery-smithsonian.html.

Encyclopedia Britannica. "Ku Klux Klan I Definition \& History." Accessed April 13, 2021. https://www.britannica.com/topic/KuKlux-Klan.

Encyclopedia Britannica. “Uncle Tom's Cabin | Summary, Date, \& Significance." Accessed April 13, 2021.

https://www.britannica.com/topic/Un cle-Toms-Cabin.
Engs, Robert F. "Historical Perspectives on the Problem of Black Literacy." Educational Horizons 66, no. 1 (1987): $13-17$. https://www.jstor.org/stable/42926188.

Goldstein, Jeffrey $\mathrm{H}$. The Psychology of Humor: Theoretical Perspectives and Empirical Issues. Cambridge: Academic Press, 2013.

Hart, Marjolein 't. "Humour and Social Protest: An Introduction." International Review of Social History 52, no. S15 (2007): 1-20. https://doi.org/10.1017/S002085900 7003094.

Junco, Manuel Alvarez. "Designing the Incorrect. (Design and Graphic Humor." Design Discourse 3, no. 2 (2008): 1-16.

Kress, Gunter, and Theo van Leeuwen. Reading Images: The Grammar of Visual Design. 2nd ed. New York: Routledge, 2006.

Leeuwen, Theo Van, and Carey Jewitt. The Handbook of Visual Analysis. London: SAGE Publications, 2001.

Martin, Michel. "Why African-Americans Loathe 'Uncle Tom." NPR.org, July 30, 2008. https://www.npr.org/templates/story/ story.php?storyld=93059468.

Mason, Cheryl Banks. "The Dynamics of Black Humor from Afrika to Amerika and The Transformation from Slavery to the Twentieth Century." Thesis, Clark Atlanta University, 2008.

https://radar.auctr.edu/islandora/objec t/cau.td\%3A2008_mason_cheryl_b/.

Murji, Karim. "Using Racial Stereotypes in Anti-Racist Campaigns." Ethnic and Racial Studies 29, no. 2 (2006): 260-80.

https://doi.org/10.1080/0141987050 0465488.

Nordquist, Richard. "What is Eye Dialect?" ThoughtCo, February 12, 2020. https://www.thoughtco.com/eyedialect-spelling-term-1690700. 
Rapp, Alan. "Archie Boston's Design Journey." AIGA | the professional association for design. Accessed April 13, 2021. https://www.aiga.org/designjourneys-archie-boston.

Richards, Delgado, and Jean Stefancic. Critical Race Theory: An Introduction. 3rd ed. New York: New York University Press, 2017.

Saucier, Donald A., Megan L. Strain, Stuart S. Miller, Conor J. O'Dea, and Derrick F. Till. "What Do You Call a Black Guy Who Flies a Plane?': The Effects and Understanding of Disparagement and Confrontational Racial Humor." Humor 31, no. 1 (2018): 105-28. https://doi.org/10.1515/humor-20170107.

Shaffer, Donald R. "II Do Not Suppose That Uncle Sam Looks at the Skin': African Americans and the Civil War Pension System, 1865-1934." Civil War History 46, no. 2 (2000): 13247. https://doi.org/10.1353/cwh.2000.00 49.

Shierholz, Heidi. "Likely That Nearly One in Five Black Workers was Unemployed at Some Point in 2013." Economic Policy Institute (blog). Accessed April 13, 2021. https://www.epi.org/publication/black -workers-unemployed-point-2013/.

Snape, Jason J. "Humor as an Element in Graphic Design.” Thesis, Rochester Institute of Technology, 1993. https://scholarworks.rit.edu/theses/4 746.

Sorensen, Majken Jul. "Humor as a Serious Strategy of Nonviolent Resistance to Oppression." Peace \& Change 33, no. 2 (2008): 167-90. https://doi.org/10.1111/j.1468-

0130.2008.00488.x.
Southern Poverty Law Center. "Ku Klux Klan," 2021. https://www.splcenter.org/fightinghate/extremist-files/ideology/ku-kluxklan.

The Editors of Encyclopaedia Britannica. "Uncle Sam | History, Artist, Drawing, Propaganda, \& Facts." Encyclopedia Britannica, May 5, 2020.

https://www.britannica.com/topic/Un cle-Sam.

Tricomi, Albert H. "Dialect and Identity in Harriet Jacobs's Autobiography and Other Slave Narratives." Callaloo 29, no. 2 (2006): 619-33. https://doi.org/10.1353/cal.2006.0125.

Turchiano, Danielle. "Two in Three Black Americans Don't Feel Properly Represented in Media (Study)." Variety (blog), September 17, 2020. https://variety.com/2020/tv/news/rep resentation-matters-study-nrg-blackamericans-media-1234772025/.

Weaver, Simon. "Developing a Rhetorical Analysis of Racist Humour: Examining Anti-Black Jokes on the Internet." Social Semiotics 20, no. 5 (2010):

537-55. https://doi.org/10.1080/10350330.20 10.513188.

Weissenrieder, Maureen, and Norman Fairclough. "Critical Discourse Analysis: The Critical Study of Language." The Modern Language Journal 81, no. 3 (1997): 428. https://doi.org/10.2307/329335.

Yoon, InJeong. "Why Is It Not Just a Joke? Analysis of Internet Memes Associated with Racism and Hidden Ideology of Colorblindness." Journal of Cultural Research in Art Education 33 (2016): 62-123. 